\section{HISTORICAL}

NEUROLOGY AND

NEUROSURGERY

\title{
Neurosciences in the Third Reich: from Ivory Tower to Death Camps
}

\author{
Michael I. Shevell
}

\begin{abstract}
It is commonly thought that the horrific medical abuses occurring during the era of the Third Reich were limited to fringe physicians acting in extreme locales such as the concentration camps. However, it is becoming increasingly apparent that there was a widespread perversion of medical practice and science that extended to mainstream academic physicians. Scientific thought, specifically the theories of racial hygiene, and the political conditions of a totalitarian dictatorship, acted symbiotically to devalue the intrinsic worth to society of those individuals with mental and physical disabilities. This devaluation served to foster the medical abuses which occurred. Neurosciences in the Third Reich serves as a backdrop to highlight what was the slippery slope of medical practice during that era. Points on this slippery slope included the "dejudification" of medicine, unethical experimentation in university clinics, systematic attempts to sterilize and euthanasize targeted populations, the academic use of specimens obtained through such programs and the experimental atrocities within the camps.
\end{abstract}

R SUM : Les neurosciences sous le troisi me Reich: de la tour d'ivoire aux camps de la mort. On croit en général que les abus médicaux horribles commis sous le troisième Reich ont été commis par des médecins marginaux agissant dans des lieux exceptionnels tels les camps de concentration. Cependant, il est de plus en plus évident qu'il y a eu une perversion répandue de la pratique médicale et de la science qui s'étendait aux médecins du milieu académique. La pensée scientifique, spécifiquement les théories de l'hygiène racial, et les conditions politiques d'une dictature totalitaire ont agi en symbiose pour dévaluer pour la société la valeur intrinsèque des individus ayant une incapacité physique ou mentale. Cette dévaluation a servi à encourager les abus médicaux qui ont été perpétrés. Les neurosciences sous le troisième Reich seront utilisées comme toile de fond pour illustrer la pente glissante de la pratique médicale à cette époque. La "déjuification" de la médecine, l'expérimentation non éthique dans les cliniques universitaires, les tentatives systématiques de stérilisation et d'euthanasie de populations ciblées, l'utilisation en milieu académique de spécimens obtenus par ces programmes et les atrocités expérimentales dans les camps des points de repère sur cette pente glissante.

Can. J. Neurol. Sci. 1999; 26: 132-138

For most, the phrase "Medicine in the Third Reich" conjures up the picture of a group of defendants in the prisoners' box at Nuremburg during the Medical Crimes Trial of 1946-47. ${ }^{1}$ This prosecution carried out by American judicial authorities, concerned itself with indictments against 23 individuals, 20 of whom were physicians. ${ }^{1}$ The major focus of these indictments were a number of human experiments carried out on non-consenting inmates in the concentration camps of the Third Reich. ${ }^{2}$ The rationale offered by the defendants for these horrific experiments resided in their possible relevance to medical matters faced by the armed forces of the Third Reich during the conduct of World War II. ${ }^{2}$ These experiments involved such atrocities as the exposure of humans to freezing temperatures, simulated extreme changes in altitude, typhus, malaria, epidemic jaundice, mustard gas and other poisons. ${ }^{2}$ These experiments were often fatal to the subjects who were chosen to participate and the few survivors were often horribly disabled. ${ }^{2}$ In all 16 defendants would be ultimately convicted, with death sentences handed out to seven. ${ }^{2}$
While the knowledge of these experimental atrocities and the associated visual images are quite disturbing, paradoxically they also serve, as Caplan has pointed out, to 'comfort' us. ${ }^{3}$ The 'comfort' provided is by the fostering of several "myths" regarding the actual conduct of medical practice and science in the Third Reich. ${ }^{3}$ Specifically, on the basis of the evidence presented at the Medical Crimes Trial, we are left with a 'myth' that medical atrocities were carried out only by a marginal and fringe element of German medical society. ${ }^{3}$ This, despite the fact that two of the convicted defendants included Karl Gebhardt and Gerhard Rose, the former a distinguished Berlin-based University professor of

From the Divison of Pediatric Neurology, Montreal Children's Hospital, and the Departments of Neurology/Neurosurgery and Pediatrics, McGill University, Montreal, Quebec, Canada.

RECEIVEDJULY 20, 1998. ACCEPTEDINFINALFORM NOVEMBER 17, 1998.

Reprint requests to: Dr. Michael Shevell, Room A-514, Montreal Children's Hospital, 2300 Tupper Street, Montreal, Quebec H3H 1P3 
surgery and President of the German Red Cross, and the latter the director of the Tropical Medicine Section of the Robert Koch Institute. ${ }^{2}$ The second 'myth' is that atrocities only occurred in such extreme situations and locales as the concentration camps. ${ }^{3}$ These 'myths', together with the passage of time, 'comfort' us in the present by suggesting that such events cannot ever happen again.

It is important to recall the stature of German medicine prior to the second World War. The Flexner report upon which North American medical education was reformed at the turn of the century was based largely on observations of the German medical model. ${ }^{4}$ Furthermore, the academic stature of medicine in Germany is reflected by its eight Nobel Laureates, more than any other country, prior to $1939 .{ }^{4}$ Germany had also been the first country to introduce, in the latter part of the 19th century, a statesupported medical insurance scheme and by the 1930s, extensive coverage through a combination of public and private means was provided for medical illness and care to the German population. ${ }^{4}$ As pointed out by Seidelman, German medical practice was indeed the envy of Western societies prior to the war. ${ }^{4}$

This medical enlightenment was severely corrupted with the ascension of the Nazis to power in 1933 and the founding of the Third Reich. National Socialism, the political philosophy of the Nazi Party, emphasized definitive biological solutions to what were perceived as social and racial problems within the German state. ${ }^{5}$ Racial hygiene, a science that highlighted the identification and study of those factors responsible for the decrement of the overall health of a nation or race, was an offshoot of the obsession with eugenics that was prevalent throughout the Western World during the first part of this century. ${ }^{6}$ In racial hygiene, the Nazis found a scientific (i.e. objective) rationale for their proposed biological solutions. ${ }^{5}$ In addition, with the National Socialist emphasis on biology and science, physicians and medical scientists found a conduit for enhanced professional prestige and power. ${ }^{5}$ Thus a reciprocal, indeed symbiotic, relationship existed between these two groups. Furthermore, as pointed out by Alexander in his comprehensive analysis of medicine in the Third Reich, within a totalitarian state or dictatorship, medical practice and science assumes the guiding principle of that dictatorship. ${ }^{7}$ In the Third Reich, such a principle was one of "rational utility" and medicine, as a subset of German society, was not exempt from the application of such a guiding principle to its sphere of influence.

Neuroscience in the Third Reich can be viewed as a microcosm of medicine and medical science in Germany during that era. It is representative of the corruption which occurred and for most, such corruption occurred in the mainstream of German medical practice, often in academic centers similar to our own, far removed from the extreme situations of the concentration camps. ${ }^{8}$ Reviewing what occurred also provides a telling reminder of the "slippery slope" in which incremental compromises in ethical standards begets further subsequent, even greater, ethical compromises. ${ }^{9}$

Much of what we know about neurosciences in the Third Reich is the result of the work of an Austrian-born, American neuropsychiatrist, Dr. Leo Alexander. ${ }^{10,11}$ After the fall of Germany in 1945, Dr. Alexander had a mandate from the Supreme Headquarters of the Allied Expeditionary Force (SHAEF) to conduct a post-mortum of Third Reich medicine. ${ }^{10}$
The result was a series of classified reports (Combined Intelligent Subcommittee Reports-CIOS $)^{12-18}$ which were the first to provide details of the active euthanasia program of mentally and physically handicapped children and adults as well as the horrific cold water immersion and pressure chamber experiments conducted in Dachau. Dr. Alexander would go on to be one of the two American medical consultants present at the Medical Crimes Trial at Nuremburg in 1946-47. ${ }^{11}$ The German language medical literature (scientific reports and monographs) from the middle part of this century also provide much insight into what occurred, particularly in academic settings. Jürgen Peiffer a retired neuropathologist at the University of Tübingen, has been instrumental in uncovering and documenting such academic reports and has published his findings in several recent German language publications. ${ }^{19,20}$

\section{"DeJudification" of Neuroscience}

The Civil Service Law of 1933, together with the later more well known Nuremburg race laws of 1935, provided the legal basis for the systematic marginalization of various elements of German society, specifically targeting those who were designated as non-Aryan. ${ }^{21}$ These laws excluded Jews and those with partial Jewish ancestry (one grandparent) from appointments in the Civil Service and from the full benefits of being citizens of the Reich. ${ }^{21}$ Since academic posts were considered part of the Civil Service, as were the appointments of physicians within a variety of state supported insurance schemes, health clinics and hospitals, these laws were used with great effect to remove Jews from university medical appointments. ${ }^{22}$ Systematic application of these laws, together with a hostile environment progressively narrowed the scope of medical practice and scientific endeavor open to Jews. ${ }^{22}$ These actions included; ${ }^{22} 1$ ) the restriction of medical school entry for Jews, 2) removal from academic teaching posts, 3) ineligibility for research support funding, 4) limitations in eligibility for participation as physicians in state and privately supported insurance schemes, 5) restrictions in hospital appointments, ultimately to Jewish-only hospitals, and 6) restrictions in medical practice to providing care only for Jewish patients.

These bureaucratic measures served as a powerful incentive for the emigration of Jewish physicians from the Reich, which paralleled the pre-war emigration of more than $60 \%$ of the German Jewish population. ${ }^{21}$ In addition, the totalitarian environment, with its lack of toleration of open dissent served as a strong motivator for the departure of those physicians whose political opinions (socialist or communist) were at sharp odds with those of the ruling National Socialist German Workers Party (NSDAP).

Jürgen Peiffer identified in a 1998 German language article, ${ }^{23}$ 47 German neuroscientists who emigrated unwillingly from Germany in the years 1933-1939. Such eminent names as Leo Alexander, Max Bielschowsky, Josef Gerstmann, Franz Kallmann, Friedrich Lewy and Adolf Wallenberg are included on this list. Also recorded in this paper is the death of Ludwig Pick in the Theresienstadt concentration camp in February of 1945.

\section{Sterilization and Euthanasia}

Within the framework of racial hygiene, several counterselection factors were identified that were thought to lead to an 
irretrievable degeneration of racial quality. The two most prominent counterselection factors identified by the racial hygienists were; 1) the continued medical and supportive care of weak and 'marginal' members of society and, 2) the continued reproduction of such 'marginal' members. ${ }^{6}$ Racial hygienists put little emphasis on the influence of environmental factors in determining health and went so far as to identify "sick genetic lines" that were beyond the possibility of the restoration to health. ${ }^{24}$

The Nazis were much attracted by such racial hygienic principles and were enthusiastic in their desire to apply such principles on a population-wide basis with their ascension to power. An Office of Racial Policy was established in May 1934 to coordinate the population-wide application of racial hygiene ${ }^{25}$ and the first action of this office was a sterilization law grandly titled "Law for the Prevention of Genetically Diseased Offspring". ${ }^{26}$ This law provided for the involuntary sterilization of individuals so ordered by the newly established genetic health courts. ${ }^{26}$ Two of the three justices in each of these health courts were physicians and physicians were furthermore obliged to register all cases of genetic illness of which they were aware. ${ }^{26}$ The application of this law in the mid 1930s resulted in the involuntary sterilization of an estimated 400,000 individuals (with a $1 \%$ mortality rate). ${ }^{26}$ Between 80 to $96 \%$ of all decisions for sterilization were the result of an individual's affliction with congenital feeble mindedness, schizophrenia or hereditary epilepsy. ${ }^{26}$ Given these major reasons for sterilization, neurologists, psychiatrists and pediatricians were most involved in the reporting of individuals and in the administration of these genetic health courts.

In addition to the emergence of racial hygiene as a respected mode of scientific thought, there was a concurrent emergence of the view of the mentally ill and mentally defective in purely economic terms as a national burden. ${ }^{27}$ In an influential work, Hoche and Binding felt that those with severe mental retardation were without a sense of the value of life and were an enormous national burden. ${ }^{28}$ Thus, their active elimination could be construed as a humane and allowable gesture. ${ }^{28}$ On the eve of war, mechanisms were put into place for an active euthanasia program first targeting the mentally and physically disabled children and then the mentally ill and defective adults. ${ }^{28}$ The child euthanasia program was administered by an advisory committee called the "Committee for the Scientific Treatment of Severe Genetically Determined Illness". ${ }^{29}$ Physicians were once again required to register children with mental retardation or congenital deformities. Registrations were reviewed by the committee members and children so selected were transported to various institutions throughout the Reich that were equipped with extermination facilities. ${ }^{29}$ The same committee received authorization from Hitler to institute and administer an adult euthanasia program (Aktion-T4) under the supervision of Victor Brack, a trusted Chancellery official. ${ }^{30}$ Thus gas chambers disguised as shower facilities were established at six institutions throughout Germany. ${ }^{30}$ When the adult program was discontinued in August of 1941, a total of 70,273 institutionalized adults had been transferred to these facilities and executed without the consent and knowledge of their families. ${ }^{30}$

In the administration of these two programs, child and adult, the role of neurologists was largely limited to the registration and reporting by questionnaire of those individuals included in the directives. However, Carl Schneider and Max Alexander de Crinis, Professors of Psychiatry/Neurology at Heidelberg and
Berlin respectively, were key officials in the formulation and administration of Aktion-T4. ${ }^{31}$ It is important to note that at no time were physicians obliged to report patients under their care and there was no punishment for physicians who did not report. ${ }^{32}$ Indeed, the adult euthanasia program was never legally sanctioned, as it was initiated and mandated solely by a backdated memo from Hitler to the Chancellor office. ${ }^{31}$ The fate of those individuals transferred to the various euthanasia centers were well known to professionals and the lay public alike; "the sparrows were whistling from the roof tops that the patients were not dying of natural causes" 16 commented one observer. Aside from this acquiescence and passive participation in the euthanasia programs, there is evidence of significant involvement by neuroscientists in the utilization of materials obtained through these euthanasia centers for academic purposes. ${ }^{33}$

\section{Schaltenbrand's Experiment}

Georg Schaltenbrand (1897-1979) was the pre-eminent German clinical neuroscientist of his era. ${ }^{34} \mathrm{He}$ served for slightly more than 40 years as the full Professor and Professor Emeritus of Neurology at the University of Würzburg. Prior to returning to Germany in 1928, he had served as a fellow of the Rockefeller Foundation in Boston under the supervision of Harvey Cushing. ${ }^{34} \mathrm{He}$ was even seriously considered for the post of Chairman of Neurology at Johns Hopkins University in the early 1930s. A close friend of the distinguished American neurologist Percival Bailey, he was elected unanimously as an honorary member of the American Neurological Association during Bailey's tenure as president in $1955 .{ }^{34} \mathrm{He}$ was active, initially in a right wing paramilitary organization, Stahlhelm (Steel Helmet), and was also a member of the Nazi Party, and its elite unit, the SA (Brown Shirts). ${ }^{35}$

With the onset of war, Schaltenbrand's work in his clinic at Würzburg focused on the possible causes of multiple sclerosis. Schaltenbrand was convinced that multiple sclerosis (MS) had an infectious, most likely viral etiology. He believed he had developed an animal model for multiple sclerosis by intra-cisternal injections into monkeys of cerebral spinal fluid (CSF) taken from patients with active MS. ${ }^{36}$ The experimental model tested by Schaltenbrand on patients drawn from his clinic was whether CSF taken from such monkeys could then be transferred back intra-cisternally into humans without MS, who would then be observed for subsequent MS-like changes. ${ }^{37}$ In his scientific work, Schaltenbrand acknowledged that there would be a low risk of actually inducing active MS in healthy volunteers for such an experiment and that this precluded their use. ${ }^{37}$ Instead the experiments would be justifiable in individuals who were mentally deficient or mentally ill already (Verblödete Menschen demented individuals). ${ }^{37}$

No consent was obtained from the human subjects (or their families) who underwent this experiment. The individuals were subjected to repeated serial lumbar punctures to measure the changes in the cerebral spinal fluid subsequent to the intra-cisternal CSF injections from the monkeys. ${ }^{36}$ Research was funded by the Deutsche Forschungsgemeinchaft, ${ }^{34}$ (the German equivalent of the Medical Research Council) and resulted in both a journal publication $^{35}$ and a book-length monograph entitled Die Multiple Sklerose des Menschen. ${ }^{36}$ Schaltenbrand was quite proud of this monograph published in 1943 and he arranged for it to be smuggled into Switzerland so that from there it could be conveyed, 
despite the war, to his American friends. ${ }^{8}$ In all, 45 individuals were the subjects of the experiments conducted by Schaltenbrand and there were at least two deaths during the course of the experiment. The individuals who were subjects had identified diagnoses such as catatonia, schizophrenia, mental retardation, dementia and callosal tumor. ${ }^{36}$

The subjects for the experiments originally came from a psychiatric institution in Werneck, a short distance from Würzburg and had been transferred to the neurology clinic at the University Hospital in Würzburg under the supervision of Schaltenbrand. ${ }^{37}$ It is known that individuals from the Werneck psychiatric institution were also transferred to the various adult euthanasia centers that had been established concurrently in the Reich. ${ }^{38}$

Postulating that multiple sclerosis may have a possible viral etiology was a reasonable supposition given contemporary neurologic knowledge in the late $1930 \mathrm{~s},{ }^{39}$ yet the experimental design of Schaltenbrand did not even attempt to satisfy Koch's postulates which are a necessary pre-condition (then and now) to establishing an infectious etiology for any human disease. Furthermore, no other experiments conducted before or after, attempted interspecies transfer from animals to man of diseased cerebral spinal fluid. From an ethical perspective, the experiment also violated contemporary German standards regarding human experimentation established by guidelines put forward by the Reich Ministry of the Interior in $1931 .^{40}$ These guidelines served to articulate German principles regarding the acceptable limits of human experimentation and forbade the exploitation of social hardship to undertake scientific experimentation and any experimentation in the absence of any informed consent. ${ }^{40}$ It also violated acceptable standards that can be derived from the Hippocratic oath applied to human experimentation in which the experimenter "should treat them (the subject) as though he was serving as a subject". ${ }^{4}$

The painful reality is that Schaltenbrand's experiment was conducted within the confines of an academic university center by a renowned physician with an international reputation supported by research funds obtained through peer review. It is interesting to note that there was limited post-war condemnation of this particular experiment and, in fact, criticism of the experimental design generated more debate than the original experimental design itself. ${ }^{42}$ It was felt by some (e.g. Bailey) that criticism or comments on the ethical standards of a particular experiment did not warrant coverage in "an appraisal of a scientific work". ${ }^{43}$

\section{Julius Hallervorden and the Euthanasia Centers}

Julius Hallervorden's (1882-1966) memory is now largely recalled through the eponym he shares with his mentor Hugo Spatz for a rare progressive, childhood onset neurodegenerative disease, originally described in 1922 by these neuropathologists. ${ }^{44}$ A distinguished academician, Hallervorden occupied the Chair of Neuropathology at the Kaiser Wilhelm Institut in Berlin-Buch throughout the war years and following the war was a neuropathologist at the Max Planck Institute in Frankfurt. ${ }^{44}$ Hallervorden was the Prosector (Pathologist) at the Brandenburg State Hospital and was well aware of the sudden surge in institutional deaths which began in 1939 with the establishment of an euthanasia center at the Brandenburg-Görden center. ${ }^{44}$

Hallervorden's awareness of the details of the euthanasia program is confirmed by both the statements of his personal assistant at Görden, Werner-Joachim Eicke, ${ }^{45}$ and by the text of a progress report he prepared for the German Association for
Scientific Research in December $1942 .{ }^{46}$ Hallervorden was also quite explicit regarding his knowledge of the euthanasia program in his post-war interview with Leo Alexander which is contained in one of Alexander's original CIOS reports. ${ }^{17}$

During this interview he expressed enthusiasm about the scientific potential of the pathological material that was being made available through the killing center at Görden and his desire to obtain properly fixed brains for detailed scientific study. This is perhaps best encapsulated by the following quote from Hallervorden during his interview with Alexander: "I heard that they were going to do that and so I went up to them and told them, 'Look here now, boys, if you are going to kill all those people, at least take the brains out so that the material could be utilized'." 17 Hallervorden even trained a technician, Heinrich Bunke, to assist in the removal of materials from the nervous system at the killing centers. ${ }^{19}$ Hallervorden is also documented to have directed the selection of certain children for extermination and subsequent pathological studies as their brains were suitable for a research project of his entitled "Inherited Feeble Mindedness". ${ }^{47}$ Personally dissatisfied with the quality of the children's medical records, he examined 33 such children in detail prior to their death at Brandenburg. ${ }^{47}$

Hallervorden's denial of any personal responsibility for the actions which occurred at Görden is best summarized in this quote from his interview with Alexander: "I accepted the brains, of course. Where they came from and how they came to me was really none of my business". ${ }^{17}$ Post-war concerns regarding the origins of much of Hallervorden's personal pathological collection caused the removal of the collection from continued scientific use at the Edinger Institute and its interment following a proper ceremony in $1990 .{ }^{19}$

\section{Scientific use of materials obtained through the killing centers}

Apparently striking scientific opportunity existed for those neuropathologists with an awareness of the actions being carried out at the various killing centers in the Third Reich. Large numbers of pathological materials from patients, often with rare disorders, were being made available in a very short period of time. This was an opportunity which Hallervorden and some other neuropathologists could not pass up. Jürgen Peiffer has meticulously reviewed papers published in the German language literature during and after the war years comparing registration numbers and initials cited in the publications with known lists of euthanasia victims. ${ }^{23,33}$ Following a detailed study, Peiffer could identify 31 publications containing materials derived from 104 brains obtained through the killing centers during the euthanasia program. ${ }^{23,33}$ Included among these papers were several publications by Hallervorden, of which the most cited subsequently, is the case of a fetus with cerebral dysgenesis (polymicrogyria), the result of exposure at five months gestation to carbon monoxide when the fetus's mentally ill mother was gassed. ${ }^{48}$

Ironically, to his consternation, Peiffer identified two papers of his own which he worked on after the war for which the original provenance was the killing centers. The academic use of such euthanasia-derived materials, provided to the participants in the killing centers, a veneer of scientific respect and justification. $^{44,47}$ Moral legitimacy of their actions could be construed through the rationalization of possibly contributing to the progress of mankind by providing materials for study, in the hope that further disease may be alleviated. 


\section{Experimentation in the Death Camps}

Ambitious physicians realized the unlimited potential for human experimentation within the concentration camps. ${ }^{2}$ Sigmund Rascher (1909-1945), a researcher in neurophysiology, was an example of such an ambitious physician. ${ }^{31}$ Rascher had close connections to Heinrich Himmler, leader of SS, through his wife who has been described variously as Himmler's secretary, landlady or mistress. Originally a Captain in the Luftwaffe Medical Service, Rascher requested in writing from Himmler permission to conduct experiments on humans at the Dachau Concentration Camp. ${ }^{49}$ Rascher fully recognized in his original letter that the experiments he was proposing to conduct were "terminal experiments" in which the death of the experimental subjects was part of the experimental plan: "It was to be expected that nobody would volunteer for such experiments in which the experimental subjects might die." 49

The initial experiment conducted by Rascher involved the simulation of a rapid or slow descent with and without supplemental oxygen from great heights in a low pressure chamber. ${ }^{14,49}$ These experiments were conducted between March and May 1942 and the subjects were drawn, without their consent, predominantly from among political prisoners at the Dachau camp. ${ }^{14,49}$ Rascher himself attempted the simulated descent but had to terminate it abruptly because of the extreme pain and agony it caused him. ${ }^{14}$ This personal experience did not prevent him from carrying out extensive experimentation at the camps. ${ }^{14}$ An estimated 70 to 80 fatalities occurred during the conduct of the experiments and as part of the experimental design, vivisection was carried out on these fatalities even prior to the heart completely stopping, as noted by one of the assistants involved in the experiments. ${ }^{49}$ The results of the experiments were contained in a secret report prepared by Rasher entitled "Experiments on Escape from High Altitude" dated July 22, 1942. ${ }^{14,49}$

The second series of experiments conducted by Rascher involved the exposure to profound hypothermia by the immersion of subjects in a large bath of ice cold water. ${ }^{50}$ The experimental design resembled that conducted utilizing small animals by Dr. G.A. Weltz, the lead investigator at the Institute for Aviation Medicine in München. ${ }^{15}$ Various methods of rewarming were attempted and the results described. The existence of these experiments were discovered by Dr. Alexander and detailed in his CIOS Report entitled "The Treatment of Shock from Prolonged Exposure to Cold, Especially in Water". ${ }^{15}$ These hypothermia experiments were conducted, again at Dachau, from August 1942 until May 1943. ${ }^{15,49}$ These experiments were a methodological quagmire. ${ }^{50} \mathrm{Up}$ to 300 subjects underwent this experiment with death occurring in close to 100. An interim report on the experiments and the results obtained were presented by Rascher to a medical conference in October 1942 entitled "Medical Questions in Marine and Winter Emergencies". 49 A top secret report entitled "Freezing Experiments with Human Beings" was also prepared. ${ }^{49}$ Because of personal conflicts, Rascher's Luftwaffe collaborators removed themselves from the conduct of the experiment in October 1942 and Rascher continued alone in his experimental work at Dachau until May 1943. ${ }^{49}$ It was during this time that attempts were made to utilize "animal heat" provided by naked female prisoners obtained from the brothel section of the camp at Ravensbrück as a method of rewarming. ${ }^{49}$ The results of such attempts were recorded in meticulous details. ${ }^{15,49}$

Rascher was quite proud of his work with humans. This is actually summarized in a chilling quote recalled by a German physiologist, who himself utilized animals in his experimental work, to whom Rascher said at a meeting: "I (Rascher) am the only one in this whole crowd who really does and knows human physiology because I experiment on humans and not on guinea pigs or mice." ${ }^{15}$ Rascher also attempted to use the data from the hypothermia experiments as part of his habilitation thesis. The need for secrecy prevented his submission of this thesis to universities at München, Warbürg and Frankfurt. ${ }^{49}$ However, the thesis was submitted to the SS run medical faculty at the University in Strassbürg. ${ }^{49}$

In a twist of fate, Rascher would be executed upon the orders of Himmler just several weeks prior to the collapse of Nazi Germany in $1945 .{ }^{48}$ He was executed because of the concern that he would be quite outspoken regarding his activities during the war, implicating many others. ${ }^{32}$ In addition, he had conducted fraudulent experiments on a supposed antibiotic called Polygal which had turned out to be merely fluorescent water. ${ }^{32} \mathrm{He}$ had also deceived Himmler and the SS by claiming as his own several male children who in reality had been abducted gypsy children. ${ }^{32}$

\section{COMMentary}

While the experimental atrocities that occurred in the concentration camps were one component of medical practice during that era, much that can be considered a perversion of medicine occurred in the more traditional settings of the medical clinic, the chronic care institution, the university hospital and academia among the mainstream of physicians. Furthermore, the experimental atrocities did not arise de novo, but rather chronologically and morally they occurred at the end of a slippery slope prior to which much had transpired incrementally. ${ }^{9}$

The most important question to consider regarding the course of medicine in the Third Reich from our present perspective is why? Why did a noble profession, founded on the principles of primum non nocere and a Hippocratic oath that obligates the physician to act in the best interests of the patient, at the highest level of professionalism then existent, engage in such reprehensible behaviors on such a wide front? The possible answer to this important question has been considered thoughtfully by many analysts of this era and is likely to be multi-faceted in its components.

The totalitarian structure of Nazi Germany effectively devalued individual autonomy, removing any potential conflicts that may naturally exist between such autonomy and medical practice or science. ${ }^{7}$ This effectively freed practitioners and scientists from the fundamental ethical constraint that concerns itself with the protection of individual autonomy. ${ }^{51}$ This resulted, somewhat paradoxically for a totalitarian society, in a scientific pursuit that was unfettered and free, limited only by the paradigms of the experiments formulated and those scientific questions relevant to the goals of the totalitarian regime. ${ }^{52}$ Scientific objectivity can breed detachment and in such a setting this objectivity can be marked by depraved indifference and callousness to human suffering that may occur within the course of the pursuit of knowledge. ${ }^{44}$ This was further facilitated by a totalitarian regime that emphasized "rational utility", where ends held to be noble can justify horribly ignoble means. 
Another facet may lie in the symbiotic relationship that existed between medical science and National Socialist doctrine in the Third Reich. ${ }^{5}$ Within the context of a regime that considered as acceptable biological solutions (i.e. physical elimination) to political, social or racial problems, ${ }^{6}$ physicians were considered, given their expertise, as potential agents ("the needle belongs in the hands of the doctor") for the implementation of these biological solutions. ${ }^{32}$ With the primacy of racial hygienic thought, the primary role of the physician changed within society from that of an agent responsible for healing and the alleviation of suffering to one in which the physician was acting as "the guardian of the genetic constitution" of the nation with a greater responsibility to the collective (nation/state/people) than to the individual. ${ }^{15}$ This shift was aptly and chillingly summarized by Fritz Bartels of the Nazi Physicians' League in 1935: “The primary task of the physician is to discover for whom health care at government expense will be worth the cost." ${ }^{3}$ Medical "science" provided the rationale and indeed the methodology for these biological solutions. It was physicians who designed the original gas chambers disguised as shower facilities for use in an euthanasia center. Medicine became an agent of political power and physicians were rewarded by an enhanced prestige and professional status. ${ }^{5}$ Physicians at that time recognized this explicitly by their involvement in the political structure of the Nazi party and its elite groups in percentage terms far greater than that for any other professional or occupational group. ${ }^{54}$

Medicine is but a subset of society as a whole and is not exempt from prevailing influences. Medicine within a dictatorship, becomes "subordinated to the guiding philosophy of the dictatorship".7 A brutal, capricious regime such as existed throughout the Third Reich has a profound influence in brutalizing a profession and its adherents, thus affecting collective and individual actions. ${ }^{55}$ Group (e.g. Nazi Physician's League) sanctioning of such actions created a condoning and tolerant atmosphere for acts that were previously considered reprehensible. ${ }^{56}$

Perhaps the most important, and indeed fundamental, facet to consider underlying the perversion of German medicine during the Third Reich is the widespread devaluation of the intrinsic worth of an individual. ${ }^{57}$ "Personhood" was thought to be an extrinsic variable that could be objectively measured and thus defined, whether it be intelligence, physical ability, personal productivity or racial affiliation. ${ }^{9}$ Furthermore, the actual worth of an individual was considered to be equivalent to this objective extrinsic valuation. Often the analysis of such worth was couched in stark economic terms from a national perspective against a backdrop of limited resources. ${ }^{32}$ As noted by Alexander, this substantial shift in valuation that ultimately resulted in the depersonalization of many of those that were valuated by this process, occurred first in the realm of health care and predated the later horrors inflicted on larger segments of society: "The beginning at first was merely a subtle shift in emphasis in the basic attitude of physicians that there is such a thing as a life not worthy to be lived. This attitude, in its early stages, concerned itself merely with the severely and chronically sick. Gradually the sphere of those to be included in this category was enlarged to encompass the socially unproductive, the idealogically unwanted and finally all non-Germans." This devaluation was rendered explicit by those involved, as revealed by these instructions by the euthanasia team to the chemist in charge of the Criminal
Technical Institute (Dr. Albert Widmann) to develop toxic substances in sufficient amounts; "to kill animals in human form: that means the mentally ill, whom one can no longer describe as human and for whom no recovery is in sight". ${ }^{31}$

Totalitarian thought and political structure is not limited to the Third Reich. Neither is the continual conflict between individual autonomy and ethical medical practice and research. Cost-benefit analyses that over-emphasize extrinsically measurable costs and under-estimate difficult-to-measure intrinsic benefits are ubiquitous. These often occur in a setting of declining resource allocation and possible rationing in health care. Pressure upon a profession to shift its focus and primary obligation from the individual to the "group" are also frequently present. Given these points, it is relevant to study the history of medicine in one of its darkest passages and be reminded of this observation from a late 18th century German physician, Christopher Hufeland: "If the physician presumes to take into consideration in his work whether a life has value or not, the consequences are boundless and the physician becomes the most dangerous man in the state."

\section{REFERENCES}

1. Trials of War Criminals Before the Nuremberg Military Tribunals Under Control Council Law No. 10; Military Tribunal, Case 1, United States v. Karl Brandt et al., December 1946-August 1947. Washington, DC: Superintendent of Documents, U.S. Government Printing Office, 1950.

2. Mitscherlich A, Mielke F. Doctors of infamy: the story of the Nazi medical crimes. New York: Henry Schuman Publishing, 1949.

3. Caplan AL. How did medicine go so wrong? In: Caplan AL, ed. When medicine went mad: bioethics and the Holocaust. Totowa, NJ: Humana Press, 1992: 53-92.

4. Seidelman WE. Nuremberg lamentation: for the forgotten victims of medical science. Br Med J 1996; 313: 1463-1467.

5. Proctor RN. Political biology: doctors in the Nazi cause. In: Racial Hygiene-Medicine Under the Nazis. Cambridge, MA: Harvard University Press, 1988: 64-94.

6. Proctor RN. Origins of racial hygiene. In: Racial Hygiene-Medicine Under the Nazis. Cambridge, MA: Harvard University Press, 1988: 10-45.

7. Alexander L. Medical science under dictatorship. N Engl J Med 1949; 221: 39- 47.

8. Alexander L. Foreword. In: Mitscherlich A, Mielke F. Doctors of infamy: the story of the Nazi medical crimes. New York: Henry Schuman Publishing, 1949: XXIX-XXXIV.

9. Macklin R. Which way down the slippery slope? Nazi killing and euthanasia today. In: Caplan AL, ed. When Medicine Went Mad: Bioethics and the Holocaust. Totowa, NJ: Humana Press, 1992: 173-200.

10. Shevell MI. Neurology's witness to history: The Combined Intelligence Operative Sub-Committee Reports of Leo Alexander. Neurology 1996; 47: 1096-1103.

11. Shevell MI. Neurology's witness to history (Part II): Leo Alexander's contributions to the Nuremberg Code (1946 to 1947). Neurology 1998; 50: 274-278

12. Alexander L. The medical school curriculum in wartime Germany. CIOS, Item No. 24, File No. XXVII-71, 1-21.

13. Alexander L. Methods of influencing international scientific meetings as laid down by German scientific organizations. CIOS, Item No. 24, File No. XXVIII-8, 1-32.

14. Alexander L. Miscellaneous aviation medical matters. CIOS, Item No. 24, File No. XXIX-21, 1-165.

15. Alexander $\mathrm{L}$. The treatment of shock from prolonged exposure to cold, especially in water. CIOS, Item No. 24, File No. XXVI-37, $1-228$.

16. Alexander L. Public mental health practices in Germany: sterilization and execution of patients suffering from nervous or mental disease. CIOS, Item No. 24, File No. XXVIII-50, 1-173. 
17. Alexander L. Neuropathology and neurophysiology, including electroencephalography, in wartime Germany. CIOS, Item No. 24, File No. XXVII-1, 1-65.

18. Alexander L. German military neuropsychiatry and neurosurgery. CIOS, Items No. 24, File No. XXVIII-49, 1-138.

19. Peiffer J. Neuropathology in the Third Reich. Brain Pathol 1991; 1: 125-131.

20. Peiffer J. Hirnforschung im Zwielicht: Beispiele verführbarer Wissenschaft aus der Zeit des Nationalsozialismus. Husum: Matthiesen Verlag, 1997.

21. Friedlander S. Nazi Germany and the Jews: Years of Persecution, 1933-1939 (Vol 1). New York: Harper Collins, 1997.

22. Proctor, RN. Anti-Semitism in the German medical community. In: Racial Hygiene-Medicine Under the Nazis. Cambridge, MA: Harvard University Press, 1988: 131-176.

23. Peiffer J. Die Vertreibung deutscher Neuropathologen 1933-1939. Nervenarzt 1998; 69: 99-109.

24. Fischer E. Die Fortschritte der menschlichen Erblehre als Grundlage eugenischer Bevölkerungspolitik. Dtsch Med Wochenschr 1933; 59: 1069-1070.

25. Ramm R. Ärztliche Rechts-und Standeskunde, der Arzt als Gesundheitserzieher (2nd ed) Berlin: W de Gruyter, 1943.

26. Proctor RN. The sterilization law. In: Racial Hygiene-Medicine Under the Nazis. Cambridge, MA: Harvard University Press, 1988: 95-117.

27. Klee E. Euthanasie im NS-Staat, Die "Vernichtung lebensunwerten Lebens", Frankfurt: Fischer Taschenbuch-Verlag, 1983.

28. Hoche A, Binding R. Die Freigabe der Vernichtung lebensunwerten Lebens. Leipzig: F Meiner, 1920.

29. Parent S, Shevell MI. The 'first to perish': child euthanasia in the Third Reich. Arch Pediatr Adolesc Med 1998; 152: 79-86.

30. Friedlander H. Killing handicapped adults. In: The Origins of Nazi Genocide; From Euthanasia to the Final Solution. Chapel Hill: University of North Carolina Press, 1995: 62-85.

31. Burleigh M. Death and Deliverance: Euthanasia in Germany 19001945. Cambridge: Cambridge University Press, 1994: 93-129.

32. Proctor RN. The destruction of "lives not worth living." In: Racial Hygiene-Medicine Under the Nazis. Cambridge, MA: Harvard University Press, 1988: 177-222.

33. Peiffer J. Neuropathological use of the brains of murdered victims of Nazi Euthanasia. (Submitted).

34. Shevell MI, Evans BK. The "Schaltenbrand experiment," Würzburg, 1940: Scientific, historical, and ethical perspectives. Neurology 1994; 44: 350-356.

35. Schaltenbrand file, Berlin Document Center, Berlin.

36. Schaltenbrand G. Nachweis eines Virus als Ursache des übertragbaren Markscheidenschwundes. Klin Wochenschr 1940; 10: 840841.
37. Schaltenbrand G. Die Multiple Sklerose des Menschen. Leipzig, Georg Thieme, 1943.

38. Rathofer E. Archiv Institut für Zeitgeschichte (München), personal communication.

39. Innes JRM, Kurland LT. Is multiple sclerosis caused by a virus? Am J Med 1952; 12: 574-585.

40. Sass HM. Reichsrundschreiben 1931: pre-Nuremberg German regulations concerning new therapy and human experimentation. J Med Philos 1983; 8: 99-111.

41. Grodin MA. Historical origins of the Nuremberg Code. In: Annas GJ, Grodin MA, eds. The Nazi Doctors and the Nuremberg Code: Human Rights in Human Experimentation. New York: Oxford University Press, 1992: 121-144.

42. Anonymous. Book review - Die Multiple Sklerose des Menschen. Arch Neurol Psychiat 1950; 63: 190.

43. Bailey P. Letter to the editor. Arch Neurol Psychiat 1950; 63: 790.

44. Shevell MI. Racial hygiene, active euthanasia, and Julius Hallervorden. Neurology 1992; 42: 2214-2219.

45. Muller-Hill B. Interview with Werner-Joachim Eicke. In: Murderous Science. Oxford: Oxford University Press, 1988: 159.

46. Bundesarchiv, Koblenz, R73-11449.

47. Aly G. Je mehr, desto lieber. Über den umgang mit Präparaten von Nazi-Opfern vor 1945 und danach. Die Zeit 1989; 10: 21-22.

48. Hallervorden J. Ueber eine Kohlenoxydvergiftung im Fetalleben mit Entwicklungsstörung der Hirnrinde. Allg Z Psychiatr 1949; 124: 289-298.

49. Mitscherelich A, Mielke F. Experiments involving high altitude (subjection to low pressure), low temperature, and the drinking of sea water. In: Mitscherlich A, Mielke F. Doctors of Infamy: the Story of the Nazi Medical Crimes. New York: Henry Schumann Publishing, 1949: 4-41.

50. Berger RL. Nazi science - the Dachau hypothermia experiment. N Engl J Med 1990; 322: 1435-1440.

51. Lifton RJ. Participants. In: The Nazi Doctors: Medical Killing and the Psychology of Genocide. New York: Basic Books, 1986: 103-133.

52. Muller-Hill B. Nine questions. In: Murderous Science. Oxford: Oxford University Press, 1988: 88-106.

53. Bartels F. Internationales Ärztliches Bulletin 1935: 124-125.

54. Kater MH. Doctors under Hitler. Chapel Hill, NC: University of North Carolina Press, 1989.

55. Lifton RJ. Doubling: the Faustian bargain. In: The Nazi Doctors: Medical Killing and the Psychology of Genocide. New York: Basic Books, 1986: 418-465.

56. Alexander L. War crimes and their motivation. J Criminal Law Criminology 1948; 39: 298-326.

57. Seidelman WE. "Medspeak" for murder: the Nazi experience and the culture of medicine. In: Caplan AL, ed. When Medicine Went Mad: Bioethics and the Holocaust. Totowa, NJ: Humana Press, 1992: 271-279. 